\title{
India seeks to learn the lessons of the Maharashtra earthquake
}

New Delhi. The Indian Government has set up a panel of experts to investigate possible lapses by key scientific agencies responsible for monitoring and predicting earthquakes in the wake of the disastrous Maharashtra earthquake two weeks ago.

In particular, the panel - which has been given a month to report its conclusions - will look into allegations that vital seismic data about the region were not properly interpreted to assess the potential hazard. It will also investigate claims that senior geologists were quarrelling among themselves while strains were building up under Maharashtra.

At least 14 major agencies are involved in earthquake studies in India. P. R. Kumaramangalam, the science minister, says that the inquiry panel will not carry out a witch-hunt. But it "will examine all available seismic data pertaining to the region and assess if follow-up actions were taken by the agencies concerned".

The panel will also suggest fresh surveys and studies of the region, for which the Ministry of Science and Technology is already seeking a \$25 million grant from the government. "We have been focusing on Himalayan quakes for too long", says Kumaramangalam. "The time has come to look at the Deccan plateau, which we had assumed to be stable."

The earthquake, which took place on 30 September, registered 6.4 on the Richter scale. It left roads and engineered constructions intact, but flattened houses made of mud and stone in 35 villages, killing about 12,000 people officially, although unoffi-

\section{Industrial take-over for UK science policy}

London. Six of the ten non-government members of Britain's Council for Science and Technology, the newly created body responsible for providing advice to the government on issues of "strategic national importance", are to be industrialists.

Announcing the members of the council on Monday, Prime Minister John Major said that these would include Richard Sykes, chief executive of Glaxo Holdings plc, Alan Rudge, director of development at British Telecom, and Sir Robin Nicholson, formerly science adviser to Margaret Thatcher and now director of Pilkington plc.

Nicholson was previously chairman of the Advisory Council on Science and Technology, the body whose role has been taken over by the new council following publication of the government's white paper on the organization of science earlier this year.

The other members of the committee -

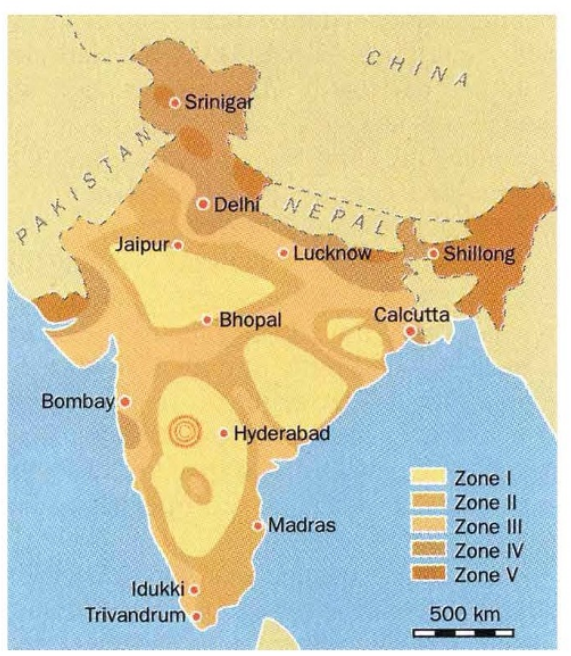

The Maharashtra earthquake occurred in a region $200 \mathrm{~km}$ west of Hyderabad, with low relative seismicity.

cial estimates are as high as 30,000 . Scientists admit that the toll would have been lower if the state administration had been correctly warned about the hazard potential, and had pushed for the construction of earthquake-proof houses. According to Kumaramangalam, one of the jobs facing the panel is to find out whether the agencies had sufficient data to warrant an alert, and if so, why they failed to issue a warning.

The Maharashtra quake was the second major earthquake in living memory to hit the Indian peninsula, long considered to be seismically stable. The first, with a magnitude of 6.7 , struck the Koyna reservoir in

which will be chaired by the minister for science, William Waldegrave - include Bridget Ogilvie, director of the Wellcome Trust, Sir Aaron Klug, director of the MRC Laboratory of Molecular Biology, and Stewart Sutherland, chancellor of the University of London.

Further evidence of the new thrust in science policy comes with the appointment of a top industrialist, widely credited for salvaging the British government's LINK scheme for bringing together university and industry research groups, as chairman of the Natural Environment Research Council.

In the first of a series of appointments flowing from the reorganization of British science outlined in the government's white paper, Robert Malpas, chairman of the Cookson Group plc, has been appointed to the new part-time position.

David Dickson
1967. But most geologists, including Harsh Gupta, director of the National Geophysical Research Institute (NGRI) in Hyderabad, believed that it was caused by the weight of water in the reservoir.

Smaller quakes had been recorded in the Deccan plateau since then. But seismologists did not think it necessary to revise India's seismic zoning map. Indeed, the epicentre of the new earthquake lies in a zone at the bottom of a seismic scale of I to V (see figure). "It was a total surprise", said Gupta.

But the earthquake has already exposed fissures in the scientific establishment. Janardhan G. Negi, until recently deputy director of NGRI, points out that he and his colleague, N. Krishna Brahmam, produced evidence in 1973 of a $390-\mathrm{km}$ long rift valley under the deccan traps. "We warned two decades ago that areas over this Kurdwadi rift needed careful monitoring, but nobody listened to us", says Negi. "The epicentre of the present earthquake sits right on the rift."

Negi, who is now science adviser to the Madhya Pradesch government, says that the epicentres of three earlier mild earthquakes also fell over the same rift, and points out that the Geological Survey of India recorded 125 tremors in the three months preceding the latest quake.

"These data, plus our prediction of a rift zone under this region, should have prompted NGRI to rush a few mobile monitoring stations to the site, but this did not happen", says Negi, who claims that leading geologists failed to pay sufficient attention to what was happening in the region.

Gupta says the Maharashtra earthquake has forced a review of the seismic status of the Deccan plateau, but is not yet prepared to admit that the Kurdwadi fault exists. Gupta and H. N. Srivatsava, deputy chief of the Indian Meteorological Department (IMD), say that its existence must be confirmed by field observation.

A team from IMD, as well as another from Germany, are already at the site measuring micro-earthquakes. Srivatsava says that these data, when combined with records of 30 September earthquake from seismic observatories around the world, will allow scientists to locate the fault and understand the mechanism behind the quake.

Meanwhile the political fallout from the earthquake is already causing concern for the ruling parties both in Delhi and in the state of Maharashtra. One month away from elections in four states, opposition parties have launched a campaign criticizing ruling politicians for ignoring pleas for relocation from villagers who died. K. S. Jayaraman 